\title{
Representasi Tubuh Ideal Pria dalam Iklan L-Men 2018: Men’s Guide
}

\author{
Jagat Senoaji \\ Program Studi Ilmu Komunikasi, Universitas Muhammadiyah Yogyakarta, Indonesia \\ jagat.senoaji.isip19@mail.umy.ac.id \\ Winanda Prasetyawan Bagaskara \\ Program Studi Ilmu Komunikasi, Universitas Muhammadiyah Yogyakarta, Indonesia \\ winanda.p.isip19@mail.umy.ac.id \\ Raihan Razin B. \\ Program Studi Ilmu Komunikasi, Universitas Muhammadiyah Yogyakarta, Indonesia \\ raihan.razin.Isip19@mail.umy.ac.id \\ Diserahkan: 10 Mei 2021; Direvisi: 10 Juni 2021; Diterima: 11 Juni 2021
}

\begin{abstract}
This study focuses on the representation of masculinity which is part of the male body commodity in the "Gain Mass-Man Guide 2018" version of the L-Men Gain Mass milk advertisement. This L-Men 2018: Men's Guide advertisement is a body-building milk advertisement with the entire cast played by a burly man. This research uses Roland Barthes' semiotic analysis technique. The results of this study indicate that this advertisement illustrates that the ideal man must have a tall body, six pack body, handsome and sharp nose. In this advertisement, there are several supporting attributes that show the representation of masculinity in this advertisement, starting from the clothes worn such as suits and shirts as well as nice and luxurious pants. Then the sports activities carried out are extreme sports which are a description of masculinity.
\end{abstract}

Keywords: L-Men Milk Ad, Masculinity, Representation

Abstrak

Penelitian ini berfokus pada representasi maskulinitas yang merupakan sebagian dari komoditas tubuh laki-laki dalam iklan susu L-Men Gain Mass versi Gain Mass-Man Guide tahun 2018. Iklan L-Men 2018: Men's Guide ini merupakan iklan susu pembentuk badan dengan seluruh pemerannya diperankan oleh pria yang bertubuh kekar. Penelitian ini menggunakan teknik analisis semiotika Roland Barthes. Hasil dari penelitian ini yaitu menunjukkan bahwa iklan ini menggambarkan bahwa laki-laki ideal adalah harus memiliki badan yang tinggi, tubuh six pack, tampan dan hidung mancung. Dalam iklan ini ada beberapa atribut pendukung yang menunjukan representasi maskulinitas dalam iklan ini yaitu mulai dari pakaian yang dikenakan seperti jas dan kemeja juga celana yang bagus dan mewah. Kemudian aktivitas olahraga yang dilakukan merupakan olahraga ekstrim yang menjadi gambarana sebuah maskulinitas.

Kata Kunci: Iklan Susu L-Men, Maskulinitas, Representasi 


\section{PENDAHULUAN}

Iklan merupakan suatu bentuk informasi produk maupun jasa dari produsen kepada konsumen maupun penyampaian pesan dari sponsor melalui suatu media, dalam hal ini iklan bertujuan untuk mengubah, mempersuasi, atau untuk mempengaruhi sikap khalayak banyak. Munculnya Iklan berguna untuk memperkenalkan produk agar konsumen dapat terpengaruhi dan sebuah pesan dari iklan diharapkan dapat diterima oleh masyarakat (Lukitaningsih, 2013).

Representasi laki-laki dan perempuan dalam iklan merupakan hal penting karena iklan atau media sering kali memberikan tampilan proporsi tubuh yang menurut mereka (pelaku iklan) ideal seperti langsing, kekar, berotot bagi laki-laki dan tidak melar sebagai bentuk tubuh yang ideal dan sempurna bagi laki-laki maupun perempuan. Nantinya laki-laki maupun perempuan akan merasa tidak percaya diri akan bentuk tubuhnya dan merasa tubuhnya tidak ideal atau tidak sempurna. Dari tampilan iklan seperti itu pada akhirnya menimbulkan permasalahan baru di masyarakat Indonesia yang terkhusus pada anak-anak remaja yang masih dalam masa pertumbuhan yang pada akhirnya terpengaruhi dan menjadi dampak negatif.

Dalam penelitiannya Riza Anggara Putra (2018) bahwa tubuh laki-laki maupun perempuan dipandang memiliki nilai jual yang tinggi di pasaran. Sehingga sosoknya dimodifikasi untuk mendapatkan keuntungan sebesar-besarnya. Bagi prosudsen pengiklan, tubuh yang six packs, kekar tidak akan surut memberikan peluang yang bisa menguntungkan. Mulai dari urusan bawah hingga urusan atas pengiklan tinggal memanfaatkan pemaknaan tentang tubuh laki-laki yang six packs, kekar, berotot untuk menentukan stereotip identitas diri, untuk pembentukan citra.

Tujuan penelitian ini akan membahas representasi tubuh ideal dalam iklan televisi Susu L-Men berusaha membentuk imajinasi tertentu melalui representasi yang dihadirkan melalui gambaran laki-laki dengan menonjolkan aspek visual pada fisik dan segala atribut yang ada pada laki-laki, mulai dari wajah, perut six packs, badan berotot hingga pakaian yang digunakan.

Tentang bagaimana representasi bentuk tubuh yang ideal dalam iklan telah menjadi obyek penelitian sebelumnya. Penelitian terdahulu dari jurnal yang relevan dan posisi penelitian dibandingkan penelitian yang terdahulu. Penelitian yang dilakukan oleh Putri Balqis (2020) bahwa dalam kajian ini, pemilihan iklan susu L-Men selain termasuk dalam jajaran merek top brand yang sering muncul di layar televisi,

Susu L-Men seringkali mengedepankan sosok laki-laki di setiap iklannya. Kajian tentang citra tubuh sebenarnya telah banyak dilakukan oleh banyak pihak, khususnya terkait dengan kesadaran tentang kajian gender, yang mempertanyakan kembali peran tubuh dalam kehidupan sosial kemasyarakatan. Citra tubuh bisa juga dikatakan sebagai sikap individu terhadap tubuhnya, baik secara sadar maupun tidak sadar, meliputi performa, potensi tubuh, fungsi tubuh serta persepsi, dan perasaan tentang ukuran tubuh dan bentuk tubuh (Hadiani et al., 2020).

Citra tubuh digambarkasn oleh seberapa jauh seorang puas akan bentuk tubuh atau bagian-bagian tubuh yang dimiliki secara keseluruhan. Sebagaimana yang umum ditemukan dalam wacana sosial kemasyarakatan, terdapat semacam pelabelan atau stereotip yang berlaku di masyarakat sesuai jenis kelamin. Pelebelan atau stereotip tentang citra tubuh ini berlangsung secara berkelanjutan karena, sistem sosial yang ada dalam masyarakat dianggap sangat kondusif dan ikut mendukung perkembangannya (Putra, 2018).

Berdasarkan hal tersebut, maka peneliti menganggap perlu adanya penelitiantentang pemahaman khalayak mengenai pemaknaan sebuah arti kata maskulinitas dalam iklan L-Men. Penelitian ini akan mencoba melihat mengenai pencitraan maskulinitas yang sebenarnya. Dalam penelitian ini, informan dipilih berdasarkan latar belakang dan kelas sosial mereka yang berbeda-beda. Laki-laki kalangan menengah ke atas dan menengah ke bawah dijadikan sebuah pembanding dalam memahami sebuah iklan yang sama, yaitu L-Men (Prasetyo, 2011). 


\section{KAJIAN PUSTAKA}

Representasi yaitu menghadirkan kembali dalam dua cara yang saling terkait, spasial, dan temporal. Kehadiran ini mengacu pada sesuatu yang tidak ada, tetapi diasumsikan sebagai sesuatu yang otentik dan berpotensi hadir. Ini merupakan Darstellung, sebuah gagasan yang membuat atau dapat menghadirkan sebuah kehadiran. Dalam mode ini, representasi tertentu memiliki kapasitas untuk membuat terlihat, disini dan dan sekarang, sesuatu yang (mungkin) hadir saat ini. ia mengakomodasi ruang dan waktu (saat ini) (Jackson, 2010).

Maskulin merupakan sebuah bentuk konstruksi kelelakian terhadap laki-laki. Laki-laki tidak dilahiran begitu saja dengan sifat maskulinnya secara alami, maskulinitas dibentuk oleh kebudayaan. Hal yang menentukan sifat perempuan dan laki-laki adalah kebudayaan. Secara umum, maskulinitas tradisional menganggap tinggi nilai-nilai, antara lain kekuatan, kekuasaan, ketabahan, aksi, kendali, kemandirian, kepuasan diri, kesetiakawanan laki-laki, dan kerja. Di antara yang dipandang rendah adalah hubungan interpersonal, kemampuan verbal, kehidupan domestik, kelembutan, komunikasi, perempuan, dan anakanak (Barker, 2007).

Di Indonesia sendiri belum ada penilaian yang ketat terhadap representasi laki-laki, praktik atau maskulinitas laki-laki dalam budaya Indonesia, termasuk perfilman Indonesia, di mana pembuat film lakilaki dan protagonis laki-laki dominan dan berpengaruh. Tetapi maskulinitas belum dibahas atau dianalisis seolah-olah itu adalah 'norma' (Heryanto, 2008). Seks dan gender: seks adalah hasil alam (kita terlahir sebagai laki-laki atau perempuan); gender, di sisi lain, adalah hasil dari budaya dan masyarakat (kita tumbuh sesuai dengan norma maskulin atau feminin) (Laughey, 2007).

Memudarnya sosialitas secara tradisional menjadi pusat identitas dan maskulinitas laki-laki yang telah banyak diinvestasikan dalam imanensi 'hal-hal yang merangkum diri' sementara perempuan secara tradisional digambarkan sebagai penanda ketergantungan dan saling ketergantungan yang sering dibingkai sebagai ancaman terhadap maskulinitas. Namun dengan ancaman ada juga daya tarik, seolaholah maskulinitas konvensional merasakan kesepian dan ketidakmungkinan imanensi murni. Tidak mungkin karena nilai - apakah nilai sebagai manusia atau nilai ekonomi - tidak dapat diukur, tidak dapat berarti, kecuali dapat dibandingkan dengan sesuatu yang lain (Wayne, 2003).

Kategori identitas yang mengacu pada karakteristik budaya yang terkait dengan menjadi seorang pria. Artinya, maskulinitas adalah konstruksi diskursif-performatif yang mendeskripsikan dan mendisiplinkan makna budaya menjadi seorang laki-laki. Maskulinitas bukanlah kualitas esensial dari subjek yang terkandung, tetapi masalah representasi, yaitu maskulinitas dibentuk oleh cara berbicara tentang dan mendisiplinkan tubuh (Barker, 2004).

\section{METODE PENELITIAN}

Seperti yang telah diterangkan di dalam pendahuluan, penelitian ini akan meneliti tentang Representasi Tubuh Ideal Pria dalam Iklan L-Men. Untuk mendapatkan jawaban dari rumusan masalah dalam penelitian ini digunakan metode semiotika. Semiotika adalah studi tentang produksi sosial makna dari sistem tanda. Studi semiotika diperkenalkan oleh ahli bahasa Swiss, Ferdinand de Saussure. Semiotika adalah ilmu yang mempelajari kehidupan tanda-tanda dalam masyarakat, dalam sebuah buku yang diterbitkan pada tahun 1916. Gagasannya tersebut dikembangkan oleh pemikir strukturalis Prancis bernama Roland Barthes, yang kemudian mempopulerkan dan memperluas semiotika pada tahun 1960 an. Saussure menggambarkan semiotika sebagai ilmu yang mengkaji tentang tanda sebagai bagian dari kehidupan sosial. Oleh Saussure, semiotika kemudian dielaborasi sebagai hubungan tripartit yakni tanda (sign) yang merupakan gabungan dari penanda (signifier) dan petanda (signified) (J. Hartley, 2003).

Semiotika sebagai usaha intelektual berusaha untuk mengungkapkan dan menganalisis sejauh mana makna dihasilkan dari hubungan struktural yang ada dalam sistem tanda apapun, dan bukan dari realitas 
eksternal yang tampak begitu alami untuk digambarkan. Karena ia berkomitmen pada gagasan hubungan sistematis yang beroperasi dalam struktur abstrak (yaitu, struktur yang tidak dapat diamati secara langsung, seperti bahasa), semiotika memiliki kecenderungan ke arah abstraksi, formalisme, dan mengabaikan landasan historis. Namun, karena ia sama-sama berkomitmen pada produksi makna secara sosial (bahasa tidak dapat ditemukan oleh individu), semiotika selalu berusaha menghubungkan produksi makna dengan jenis produksi sosial lain dan dengan relasi sosial (J. Hartley, 2003).

Jadi semiotika pertama-tama berpusat pada teks, karena ia dikhususkan untuk menganalisis bagaimana sistem makna menghasilkan makna melalui teks. Namun seiring perkembangannya, perhatian yang lebih besar telah diberikan pada peran pembaca dalam merealisasikan atau menghasilkan makna dari sumber tekstual dengan cara yang interaktif. Jadi semiotika dimulai dengan menunjukkan bagaimana teks terstruktur pengerjaan ulang tanda, kode, dan seterusnya dari sistem tanda khusus mereka, dan bagaimana struktur ini menghasilkan mitos, konotasi, dan sebagainya (J. Hartley, 2003).

Dengan demikian, semiotika berkisar tentang studi tentang tanda dalam teks. Tanda (sign) terdiri dari dua aspek, yaitu penanda (signifiant), dan petanda (signified). Penanda dapat dimengerti sebagai bentuk/wujud fisik. Penanda bisa berupa bunyi, gambar, huruf, visual dan sejenisnya. Sedangkan petanda adalah konsep atau arti dari apa yang ditandai. Relasinya antara keduanya bersifat "diada-adakan" (arbitrary), yang berarti tidak ada relasi yang sifatnya alamiah antara penanda dan petanda.

Saussure menyatakan bahwa setiap tanda (atau kata) dalam sistem bahasa terkait erat dengan sistem secara keseluruhan. Sebuah kata 'konten benar-benar ditetapkan hanya dengan persetujuan dari segala sesuatu yang ada di sekitarnya'. Untuk menggambarkan hal ini, Saussure membuat perbedaan antara bahasa (keseluruhan sistem atau struktur) dan pembebasan bersyarat (ucapan khusus dalam sistem ini) dari bahasa tertentu. Sebuah ucapan (parole) hanya dapat menandakan makna secara efektif dalam hubungannya dengan seluruh sistem bahasa (bahasa) (Laughey, 2007). Langue dan parole menjadi pemikiran Saussure yang menunjukan bahwa tanda terikat dengan struktur. Langue merupakan abstraksi dan artikulasi bahasa pada tingkat sosial budaya, sedangkan parole merupakan ekspresi bahasa pada tingkat individu. Agar lebih mudah memahaminya, langue bisa kita sebut sebagai sistem bahasa yang berlaku, sedangkan parole adalah bagaimana individu berbahasa dalam sistem tersebut. Dengan demikian, maka parole terikat dengan langue. Permainan catur bisa menjadi sebuah contoh yang bisa memperjelas tentang langue dan parole.

Setiap gerakan individu dalam catur dipilih dari seluruh sistem gerakan catur yang memungkinkan. Jadi kita bisa menyebut sistem catur yang mungkin bergerak sebagai bahasa catur. Setiap langkah individu dalam permainan catur akan dibebaskan bersyarat, pemilihan langkah dari seluruh rangkaian gerakan yang memungkinkan dalam bahasa catur (Laughey, 2007). Inilah yang menjadikan semiotika lekat dengan strukturalisme.

Pemikiran Saussure diteruskan oleh mitos Roland Barthes dengan memperluas teori Saussure tentang sistem bahasa dengan menerapkannya pada sistem di mana masyarakat dan budaya mengembangkan 'mitos'. Masyarakat dan budaya, seperti bahasa, dianggap terstruktur oleh sistem 'keseluruhan' yang menentukan bagian masing-masing. Tentu saja, bahasa sebagai sistem juga menjadi dasar bagaimana masyarakat atau budaya bertahan. Tetapi Barthes menyatakan bahwa makna linguistik murni diubah secara radikal oleh praktik sosial dan budaya (Laughey, 2007).

Gagasan yang disampaikan oleh Barthes adalah berkaitan tentang mitos. Mitos yang dimaksudkan oleh Barthes adalah pemaknaan secara konotatif dalam teks budaya populer. Pemikiran Barthes merupakan kelanjutan dari pengandaian Saussure tentang hubungan bahasa dan makna atau antara penanda dan petanda. Semiotika yang dibangun Saussure lebih bertendensi untuk menyebutkan bahwa makna sebagai apa yang didenotasikan oleh tanda. 
Gagasan ini dikembangkan oleh Barthes dengan menyebutkan bahwa sejatinya terdapat makna lain yang justru bermain pada level penandaan sekunder/kedua (secondary signification) atau pada tingkat konotasi. Pada tingkat inilah warisan pemikiran Saussure diperluas oleh Barthes dengan membongkar praktik pertandaan di tingkat konotasi tanda. Konotasi bagi Barthes justru mendenotasikan sesuatu hal yang disebutkannya sebagai mitos. Hal yang perlu dipahami adalah bahwa mitos ini mempunyai konotasi terhadap ideologi tertentu.

Dalam penelitian ini semiotika dilakukan dengan mengkaji tanda-tanda yang terdapat dalam iklan LMen. Iklan yang diteliti diposisikan sebagai teks yang merupakan rajutan dari berbagai tanda. Tandatanda yang ada baik dalam bentuk gambar, tulisan maupun suara diambil dari shoot dan scene yang ada dalam iklan L-Men. Pada tahap hasil penelitian, peneliti akan menyajikan pemaknaan secara denotatif dan konotatif, yang kemudian dilanjutkan dengan pembahasan yang menganalisis temuan penelitian dengan intertekstualitas dengan berbagai teori yang relevan.

\section{HASIL DAN PEMBAHASAN}

Pada bagian ini, peneliti memaparkan hasil dan pembahasan dari iklan susu L-Men "Gain Mass Man Guide tahun 2018”. Disini peneliti menggunakan analisis dari segi semiotika Roland Barthes yaitu denotasi, konotasi, dan mitos. Peneliti membagi scene per scene untuk melihat adanya sebuah representasi tubuh ideal dalam iklan tersebut dengan membedahnya menggunakan denotasi, konotasi dan mitos di setiap scene yang di analisis.

\section{HASIL}

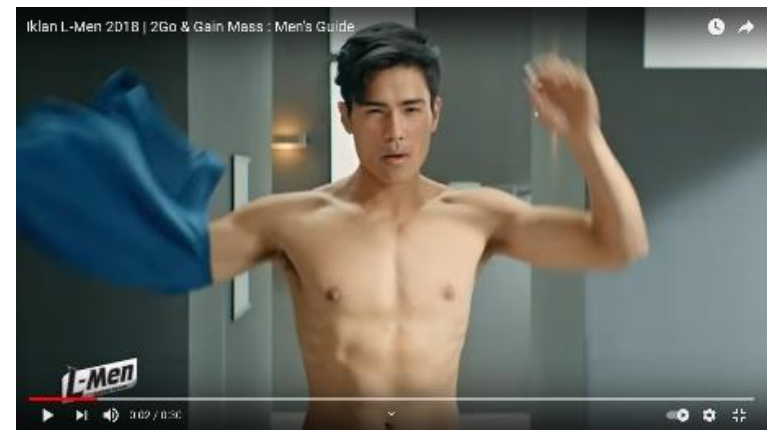

Gambar 1. Scene 1 Iklan L-Men 2018: Men's Guide

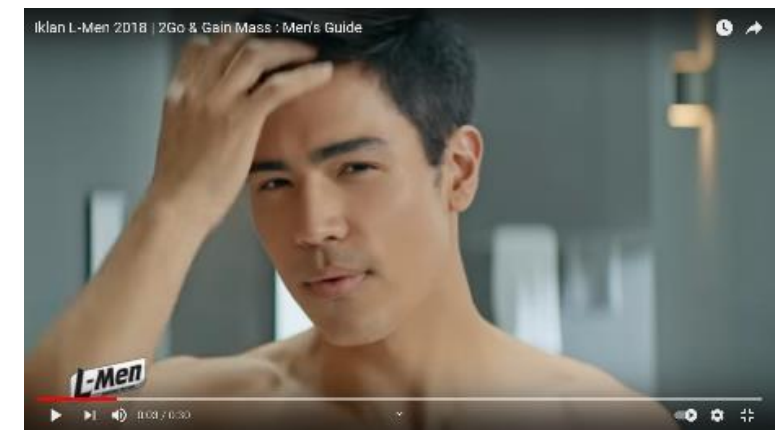

Gambar 2. Scene 1 Iklan L-Men 2018: Men's Guide

Makna denotasi: Petanda yang berada pada dalam potongan gambar 1 dari iklan di atas ialah seorang laki-laki yang membuka t-shirt warna biru dan memperlihatkan badan six pack nya, dengan berlatar belakang di dalam toilet, kemudian ketika bercermin didukung dengan audio yang berbunyi "jadi cowo milenial, rambutnya harus kekinian'. Bagian yang menjadi penanda yang sangat jelas ketika seorang pria tersebut sedang membuka bajunya yang memperlihatkan badan six pack - nya dan juga menciptakan sebuah petanda tubuh yang ideal adalah seperti yang ada pada gambar tersebut.

Makna konotasi: Badan six pack membuat percaya diri. Gambar 1 yang di tampilkan bermakna seorang laki-laki akan lebih percaya ketika memikiki badan yang ideal seperti pada iklan diatas. Adegan ini dipilih karena terlihat menghabikan uang dan waktu untuk merawat diri membentuk badan menjadi six pack. Badan dengan bentuk yang bagus menjadi salah satu penunjang penampilan sebagai seorang laki-laki, tidak hanya wanita yang selalu memperlihatkan bentuk badannya, namun seorang laki-laki juga sangat memperhatikan bentuk badannya. Seorang laki-laki juga berhak atas hal tersebut karena ada 
banyak produk susu atau suplemen pembentuk badan khusus laki-laki. Terlihat pria pada iklan tersebut menjadi percaya diri melihat badannya yang sicx pack sehingga menggambarkan sebuah makna kekuatan, maskulin dan percaya diri.

Mitos: Menambah rasa percaya diri karena badan six pack. Pada dasarnya semua laki laki ingin badan ideal atau six pack, laki-laki terkadang termasuk yang bisa dikatakan cuek dengan penampilan namun, mengingat keharusan tersebut membuat mereka mau tidak mau harus memperhatikan kesehatan dirinya. Maka, Maka munculah produk L-Men ini. Lakilaki yang memiliki perhatian lebih dengan kesehatan tubuhnya termasuk ke dalam maskulinitas pada era 2000-an yaitu maskulinitas baru atau metroseksual. Laki- laki maskulinitas adalah mereka dari kalangan menengah atas, berdandan, dan tergabung dalam komunitas terpandang.

Mitos menambah rasa percaya diri muncul karena setelah mengonsumsi susu itu bisa memabantu tubuh kita dalam membentuk tubuh sixpack dan sehat yang menimbulkan rasa percaya diri untuk menjalani aktivitas sehari-hari. Selain itu, tidak ada salahnya memperhatikan kesehatan demi penampilan yang lebih menarik. Bentuk tubuh manusia merupakan representasi diri yang pertama dan paling mudah terlihat. Dari sinilah para pria gencar untuk mendapatkan bentuk tubuh ideal, akan tetapi satu hal yang perlu diingat bentuk tubuh ideal seseorang bukan dilihat dari gemuk atau kurusnya tubuh seseorang (Ii, 2002).

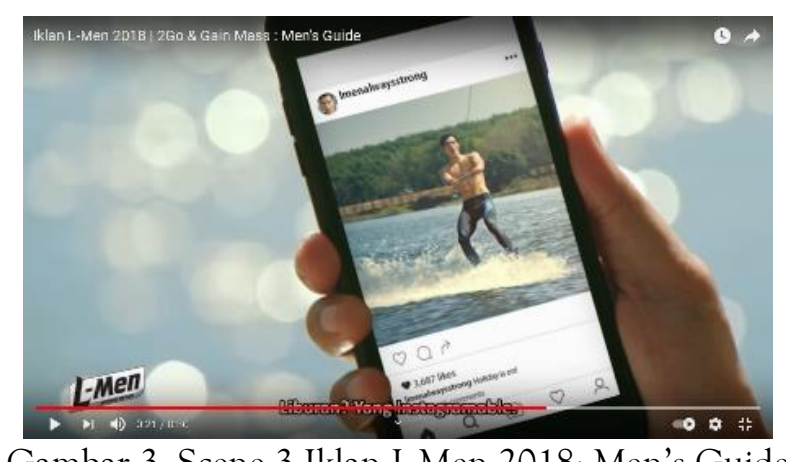

Gambar 3. Scene 3 Iklan L-Men 2018: Men's Guide

Makna denotasi: penanda dalam gambar 3 dari iklan di atas memperlihatkan seorang laki-laki yang sedang berlibur di sebuah danau. Terlihat pria tersebut juga melakukan olahraga air yaitu ski air dengan memperlihatkan tubuh nya yang six pack yang juga menggunakan celana ketat yang memperlihatkan bentuk otot pahanya tersebut. Adegan ini juga didukung dengab audio yang berbunyi "Liburan? Yang instagramable". Petanda yang muncul dalam gambar tersebut sangat jelas dimana laki-laki tersebut sedang berlibur sambil dengan menguji keberaniannya yaitu berolahraga ski air dan juga di dukung dengan aspek fisik dimana bentuk tubuh six pack laki-laki tersebut.

Makna konotasi: Pada gambar 3 dari iklan tersebut memberi makna konotasi yaitu laki-laki harus menguji keberanian saat berlibur. Tidak seperti biasanya bahwa liburan untuk bersantai, namun disini liburan sebagai menguji keberanian. Laki-laki pada iklan tersebut menguji keberaniannya dengan berolahraga ski air saat liburannya. Pada dasarnya ski air merupakan olahraga yang menggunakan kekuatan dan keberanian.

Mitos: Olahraga ekstrim yang di lakukan oleh laki-laki teresebut melambangkan kejantanan. Pada dasarnya setiap laki-laki tidak harus melakukan olah raga ekstrim untuk membuktikan kejantanannya.namun Mitos yang terbentuk disini ialah bahwa kekuatan dan keberanian merupakan ciri dari maskulinitas.karena maskulinitas tidak hanya mengacu pada sesuatu yang menantang dan ekxtrim, tetapi maskulinitas juga memiliki beberapa kategori lain yang dapat dijadikan acuan. Perkembangan 
maskulinitas memasuki dekade 1990, laki-laki cenderung mementingkan leisure time. Laki-laki senang bersenang-senang, minum bir, menonton sepak bola, melakukan hubungan seks, bahkan membuat lelucon-lelucon yang merendahkan martabat seorang perempuan (Prasetyo, 2011).

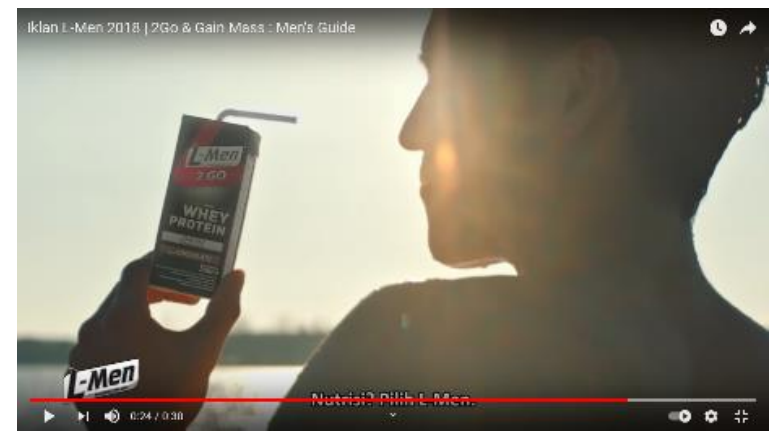

Gambar 4. Scene 3 Iklan L-Men 2018: Men's Guide

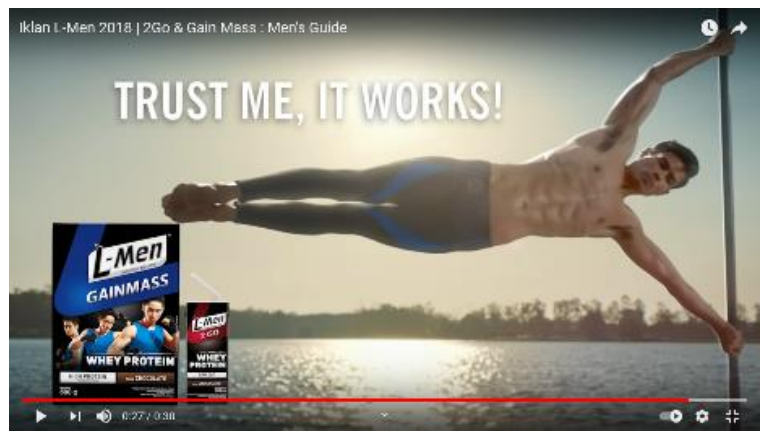

Gambar 5. Scene 3 Iklan L-Men 2018: Men's

Guide

Makna denotasi: Pada gambar iklan 4 dan 5 tersebut memperlihatkan pria tersebut meminum susu nutrisi setelah melakukan olahraga ski air. Setelah meminum susu tersebut ia melakukan sebuah kegiatan yaitu menahan tiang dalam posisi horizontal dan terlihat bentuk perutnya yang six pack, kemudian otot tangan dan badannya yang tinggi. Dengan ini menjadi penanda bentuk tubuh ideal seperti gambar di atas merupakan citra dari maskulinitas.

Makna konotasi: Dari gambar iklan tersebut terlihat bahwa sosok laki-laki itu harus kuat. Di iklan tersebut juga menampilkan ciri fisik yang ideal seperti badan six pack, wajah tampan dengan hidung mancung dan juga badan yang tinggi.

Mitos: Mitos yang dibentuk dalam iklan tersebut bahwa seorang laki-laki harus memiliki kekuatan dan bentuk badan yang ideal seperti yang ada pada gambar tersebut sebagai bentuk sosok yang maskulin dan kuat. Laki-laki yang digambarkan dalam iklan tersebut memiliki ciri fisik yaitu hidung mancung, berbentuk tubuh six pack, tinggi, dan memiki otot lengan, dan kaki yang terlihat menonjol Dengan memiliki tubuh yang ideal tersebut, laki-laki dapat memiliki kepuasan bagi pribadinya sendiri bahkan dalam kepentingannya untuk menarik lawan jenis (Prasetyo, 2011).

\section{PEMBAHASAN}

Media massa merupakan sarana utama dalam komunikasi yang memproduksi dan mendistribusikan teks dan dalam skala besar. Fungsi media disini memberikan informasi, hiburan, dan Pendidikan. Menurut Devito (1997), komunikasi massa dapat didefinisikan dengan memusatkan perhatian pada unsur-unsur yang terlibat dalam tindakan komunikasi dan mengaitkannya dengan operasional media massa. Unsurunsur yang dimaksud adalah sumber, khalayak, pesan, proses, dan konteks. Untuk menyusun dan memproduksi pesan dalam komunikasi massa, membutuhkan biaya yang sangat besar karena bekerja dalam institusi yang besar dan rumit serta melibatkan banyak orang (Abdul Halik, 2013).

Media sendiri juga memiliki fungsi lain diluar sebagai konteks menghibur, disini media juga memiliki kekuatan untuk membangun opini kepada public. Masih banyak masyarakat di luar sana yang percaya akan apa yang media tayangkan saat ini yang pada akhirnya membangun sebuah opini yang tercipta di masyarakat dan mempercayai hal tersebut.

Media juga merupakan salah satu hal yang sangat berperan dalam terciptanya atau terbentuknya maskulinitas di dalam masyarakat. Melalui media ini berbagai macam pihak mencoba untuk memberikan sebuah gambaran mengenai konsep maskulinitas ini. Dalam sebuah media, tubuh laki-laki diciptakan seperti dengan penuh makna dan berupaya memvisualkan tubuh laki-laki yang ditunjukkan dimulai 
dengan fisiknya kemudian pakaian yang dikenakan. Seiring berjalannya waktu dan perkembangan zaman saat ini, ada banyak produk berkaitan dengan laki-laki yang beredar dalam kehidupan masyarakat untuk mempresentasikan bentuk maskulinitas yang ada banyak dipasarkan. Hasil penelitian ini menunjukkan bahwa laki-laki dengan bentuk badan yang ideal ataupun six pack menjadi salah satu dari banyak aspek penampilan yang dapat menjadi sebuah nilai bagi citra diri kita. Citra tubuh merupakan sikap yang dimiliki seseorang terhadap tubuhnya berupa penilaian positif dan negatif (Cash \& Pruzinsky, 2002 ) (Nourmalita, 2016).

Tidak hanya dari bentuk tubuh yang dibentuk dalam iklan ini, Namun disini bentuk wajah juga menjadi aspek yang termasuk menjadi sebuah kontruksi maskulinitas yang digambarkan dengan bentuk wajah yang tampan, hidung mancung dan juga gaya rambut. Memiliki hidung yang terlihat mancung justru menambah kesan maskuli daripada hidung yang telihat lebih pendek sehingga bentuk wajah juga menjadi aspek yang dinilai dalam pembentukan konstruksi maskulinitas pada pria.

Di dalam iklan ini juga tidak hanya menampilkan bentuk tubuh laki-laki yang ideal. Keberanian dan kekuatan juga menjadi ciri maskulinitas yang ditampilkan oleh model dalam iklan tersebut. Keberanian yang divisualisasikan dalam iklan ini yaitu laki-laki yang menyukai olahraga yang menantang, seperti yang ada dalam iklan tersebut yaitu ski air. Ski air sendiri juga merupakan olahraga yang menguji keberanian dan nyali. Tidak hanya keberanian yang terlihat disini melainkan juga membutuhkan kekuatan untuk menjaga keseimbangan ketika berolahraga ski air ini.

Sejatinya tugas utama iklan adalah untuk mengubah produk menjadi sebuah citra, dan apapun pencitraannya yang digunakan dalam sebuah iklan, baik itu citra kelas sosial, citra seksualitas, dan sebagainya, yang terpenting pencitraan itu memiliki efek terhadap produk dan akan menambah nilai ekonomisnya (Bungin, 2008). Di dalam iklan Susu L-Man ini menjadi sebuah upaya dalam pembentukan Maskulinitas bagi pria, dengan menciptakan visual seorang pria yang memiliki tubuh yang six pack, berbadan tinggi, berwajah tampan dengan hidung yang mancung dan kegiatan yang pria dalam iklan tersebut lakukan yaitu olahraga yang menantang agar tercipta sebuah realitas bentuk maskulintas tersebut juga memiliki aspek kekuatan dan keberanian.

Dapat dikatakan bahwa gambaran sosok laki-laki yang ideal dalam iklan L-Men tersebut merupakan ciri fisik laki-laki di benua-benua Barat. Ini tergambarkan melalui gaya rambut, tinggi badan, hidung mancung, dan juga warna kulit pria tersebut. Tanpa kita sadari, Iklan L-Men ini menanamkan sebuah standarisasi bentuk tubuh ideal pria di dalam setiap iklannya yang memberi sebuah patokan di dalam iklannya bentuk tubuh pria yang ideal.

Dalam memahami perbedaan gender dan jenis kelamin, dapat disimak pemikiran Ivan Hill melalui Budiman (1999:104). Baginya, gender adalah sebuah distingsi berilaku dalam budaya vernacular. Konsep gender ini membedakan waktu, tempat, peralatan, tugas, gerak gerik, bentuk tuturan dan bermacam presepsi yang dikaitkan pada laki-laki atau perempuan. Perbedaan gender di antara kedua jenis kelamin tersebut akan menjadi lebih lebar Ketika masyarakat pun mempertahankan perbedaan, yang sifatnya bukan bawaan sejak lahir. Lebih dari itu, perbedaan itu justru dipertahankan secara kultural (Kurnia, 2004).

Heddy Shri Ahimsha Putra (2000) menegasakan bahwa istilah Gender dapat dibedakan ke dalam beberapa pengertian berikut ini: gender sebagai suatu istilah asing dengan makna tertentu, gender sebagai suatu fenomena sosial budaya, gender sebagai suatu kesadaran sosial, gender sebagai suatu persoalan sosial budaya, gender sebagai sebuah konsep untuk analisis, gender sebagai sebuah perspektif untuk memandang kenyataan (Fibrianto, 2016).Pada penelitian ini peneliti menggunakan teori semiotika dari John Fiske, dalam semiotika (ilmu tentang tanda) terdapat dua perhatian utama, yakni hubungan antara tanda dan maknanya, dan bagaimana suatu tanda dikombinasikan menjadi suatu kode (Hartley, 2003). 
Dengan demikian, Semiotika merupakan studi tentang tanda dalam sebuah teks. Tanda (sign) terdiri dari dua aspek, yaitu penanda (significant), dan petanda (signified). Penanda dapat dimengerti sebagai bentuk/wujud fisik. Penanda biasanya bisa berupa bunyi, gambar, huruf, visual dan sejenisnya. Sedangkan petanda ialah sebuah konsep atau arti dari apa yang ditandai. Relasinya antara keduanya bersifat diadakan atau (arbitrary), yang dimana berarti tidak ada relasi yang sifatnya alamiah antara penanda dan petanda.

\section{KESIMPULAN}

Setelah mengkaji dan menginterpretasikan iklan L-Men 2018: L-Men's Guide. Maka dapat disimpulkan bahwa Representasi tubuh ideal pria tidak lepas dari maskulinitas yang ditampilkan dalam iklan susu LMen "Gain Mass-Man Guide tahun 2018" terbagi dalam dua representasi yaitu penampilan fisik lakilaki maskulin dan atribut pendukung yang melambangka maskulin. Seperti melakukan olahraga ekstrim. Tirbuh ideal yang digambarkan oleh LMEN menjadi sebuah gaya hidup (life style) terhadap sosok lakilaki baru yang disebut dengan istilah metroseksual yang mencoba ditawarkan kepada konsumen. Sehingga di dalam Iklan L Man ini menciptakan sebuah realitas dimana bentuk ideal tubuh pria yaitu dengan bentuk perut yang six pack, lengan berotot, tubuh tinggi, hidung mancung, tampan, dan otot paha yang besar. Dengan bentuk-bentuk tubuh seperti itulah menjadi sebuah standar.

\section{PERSANTUNAN}

Terima kasih kepada Dr. Fajar Junaedi yang telah membimbing proses riset tentang iklan L-Men dengan menggunakan semiotika dalam mata kuliah Kajian Kritis Iklan di Program Studi Ilmu Komunikasi UMY, selama satu semester genap tahun akademik 2020/2021 yang menghasilkan luaran berupa artikel ini.

\section{REFERENSI}

Abdul Halik. (2013). Dokumentasi. 36. http://repositori.uin-alauddin.ac.id/338/1/KOMUNIKASI MASSA full.pdf

Barker, C. (2004). Bibioteca Hombres del Perú. Vol. 1. https://books.google.com.pe/books?id=iOJyAiS2gG0C\&dq

Barker Nasir. (2007). KONSEP MASKULINITAS DARI JAMAN KE JAMAN DAN CITRANYA DALAM MEDIA. (Vol. 3, Issue September).

Bungin. (2008). Bungin 2008:126. 121.

Fibrianto, A. S. (2016). Kesetaraan Gender Dalam Lingkup Organisasi Mahasiswa Universitas Sebelas Maret Surakarta Tahun 2016. Jurnal Artikel Sosiologi, 5(1), 10-27.

Hadiani, S. N., Alexandra R, S., \& Balqis, P. (2020). Representasi Maskulinitas dan Tubuh Lelaki Ideal dalam Iklan Susu L-Men. Jurnal Audiens, 1(2). https://doi.org/10.18196/ja.12027

Hartley, J. (2003). A short history of cultural studies. A Short History of Cultural Studies, 1-189. https://doi.org/10.4135/9781446216934

Hartley, J. F. dan J. (2003). J. Fiske dan J. Hartley. Antimicrobial Agents and Chemotherapy, 58(12), 72507257. https://doi.org/10.1128/AAC.03728-14

Heryanto, A. (2008). Popular culture in Indonesia: Fluid identities in post-authoritarian politics. In Popular Culture in Indonesia: Fluid Identities in Post-Authoritarian Politics. https://doi.org/10.4324/9780203895627

Ii, B. A. B. (2002). dalam Men's Health, 2004). Men's Health, 2004), lim (2009), 1-25.

Jackson, F. (2010). Understanding, Representation, Information. In Language, Names, and Information. https://doi.org/10.1002/9781444325362.ch2 
Kurnia, N. (2004). Jurnal JSP Vol.8 No.1 Jili 2004.pdf. In Jurnal Ilmu Sosial dan Ilmu Politik Universitas Gajah Mada (Vol. 08, pp. 17-36). https://repository.ugm.ac.id/37669/1/Jurnal JSP Vol.8 No.1 Jili 2004.pdf

Laughey, D. (2007). Key themes in media theory. Key Themes in Media Theory, 1-29.

Lukitaningsih, A. (2013). IKLAN YANG EFEKTIF SEBAGAI STRATEGI KOMUNIKASI PEMASARAN Ambar Lukitaningsih Fakultas Ekonomi Universitas Sarjanawiyata Tamansiswa Yogyakarta. Jurnal Ekonomi Dan Kewirausahaan, 13(2), 116-129. http://ejurnal.unisri.ac.id/index.php/Ekonomi/article/view/670/576

Nourmalita, M. (2016). Pengaruh Citra Tubuh terhadap Gejala Body Dismorphic Disorder yang Dimediasi Harga Diri pada Remaja Putri. SEMINAR ASEAN $2 \mathrm{Nd}$ PSYCHOLOGY $\mathcal{E}$ HUMANITYEAN 2 Nd PSYCHOLOGY $\mathcal{G}$ HUMANITY, 19-20. mpsi.umm.ac.id/files/file/546555 melina.pdf

Prasetyo, A. B. (2011). Maskulinitas Dalam L' Men. Jurnal Komunikator, 3(2), 205-231.

Putra, R. A. (2018). KONSTRUKSI MASKULINITAS LAKI-LAKI MELALUI KOMODIFIKASI TUBUH DALAM IKLANPRODUKSUSU L-MEN GAINMASS (ANALISIS SEMIOTIKA JOHN FISKE). Putra, R. A., Konstruksi (Konstruksi Maskulinitas Laki-laki Melalui Komodifikasi Tubuh Dalam Iklan Produk Susu L-Men Gainmass), 43-61. https://pdfs.semanticscholar.org/aee2/7cbb3884cf8aa4014dce6291bee63215e7eb.pdf

Wayne, M. (2003). Marxism and media studies: key concepts and contemporary trends. Choice Reviews Online, 41(06), 41-3240-41-3240. https://doi.org/10.5860/choice.41-3240 